\title{
Andragoška/pedagoška podpora izobraževalnih programov za menedžerje dobrega počutja
}

\author{
Andrej Mohar* \\ Fakulteta za organizacijske študije v Novem mestu, Ulica talcev 3, 8000 Novo mesto, \\ Slovenija \\ andrej.mohar@arex.si \\ Boštjan Zagorc \\ Fakulteta za organizacijske študije v Novem mestu, Ulica talcev 3, 8000 Novo mesto, \\ Slovenija \\ bostjan.zagorc@gmail.com
}

\begin{abstract}
Povzetek:
Raziskovalno vprašanje (RV): Katere so najbolj optimalni medijski formati za učno vsebino za ciljno skupino (menedžerji dobrega počutja)? Katero ogrodje ocenjevanja bi bila najbolj primerna merjenje izidov? Katere vrste pedagoške/andragoške pomoči so potrebna, da sodelujejo udeleženci (menedžerji dobrega počutja) $\mathrm{v}$ učno vsebino? Katere so najbolj primerna učne metodologije (poučevanja in učenje) za menedžerje dobrega počutja?
\end{abstract}

Namen: Namen in cilj raziskave je primerjava andragoško/pedagoške podpore izobraževalnim programov za menedžerje dobrega počutja med Slovenijo ter EU in ZDA.

Metoda: S kvalitativno metodo raziskovanja smo preučili 36 člankov in spletnih strani. Raziskava je temeljila na preučevanju teh člankov in spletnih strani na temo izobraževalnih programov za menedžerje dobrega počutja.

Rezultati: Andragoško/pedagoška podpora izobraževalnim programom za menedžerje dobrega počutja bistveno boljša $\mathrm{v}$ ZDA in EU kot $\mathrm{v}$ Sloveniji. Slovenija je na področju podpore izobraževalnih programov za menedžerje dobrega počutja še dokaj na začetku primerjalno z ostalimi državami kot so EU in ZDA.

Organizacija: Raziskava lahko pripomore tako menedžerjem kot najvišjemu vodstvu spoznati različne pristope za dosego kompetenčnih menedžerjev, kateri lahko širijo 'dobro počutje' med zaposlene.

Družba: $Z$ izobraževalnimi programi za menedžerje dobrega počutja lahko pozitivno vplivamo na zadovoljstvo in zdravje zaposlenih ter posledično na kakovostnejše življenje tako zaposlenih kot njihovih družinskih članov.

Originalnost: Raziskava podaja pregled vzorca raziskave glede na vse najdene članke, vezane na tematiko andragoško/pedagoške podpore za menedžerje dobrega počutja.

Omejitve/nadaljnje raziskovanje: Raziskava je bila omejena in narejena na podlagi teorije ter člankov in spletnih strani na podana raziskovalna vprašanja.

Ključne besede: menedžer, izobraževanje, dobro počutje, stres, medijski formati, andragogika, kovčing. 


\section{Uvod}

Menedžment je ima pomembno vlogo v življenju vsakega posameznika, zato je za menedžment podjetja zelo pomembno, da pozna svoje zaposlene in njihovo motivacijo. Menedžer je oseba kateremu osnovne naloge izhajajo iz procesa menedžmenta. V zadnjem času živimo v času hitrih sprememb zato je dobro počutje ključ do uspešnosti organizacije in njenih zaposlenih. Obstajajo različni pristopi za izboljšanje dobrega počutja na delovnem mestu in poslovno uspešnostjo. Med njimi se v zadnjem času vse bolj uveljavljajo izobraževalni programi dobrega počutja za menedžerje. Menedžerji se vse bolj zavedajo, da so zaradi preobremenjenosti vsakodnevno pod stresom. Zavedajo se tudi, da dolgotrajni stres pripelje do izgorelosti zato se vse bolj poslužujejo teh izobraževanj.

Ključni dejavnik pri odločanju o dolgoročni uspešnosti organizacije je dobro počutje zaposlenih, kar tudi kažejo številne študije neposredno povezavo med stopnjo produktivnosti in splošnim zdravjem ter blaginjo delovne sile. (Mednarodna organizacija dela, 2020, ods. 2)

Namen in cilj raziskave je primerjava andragoško/pedagoške podpore izobraževalnih programov za menedžerje dobrega počutja med Slovenijo, EU in ZDA. Z raziskavo želimo ugotoviti kje imajo menedžerji boljšo podporo andragoško/pedagoških izobraževalnih programov dobrega počutja.

\section{Teoretična izhodišča}

\subsection{Vloga izobraževanja}

Razvoj kadrov je osrednje področje menedžmenta človeških virov v organizacijah, v sklopu katerega se srečujejo naloge svetovalcev v izobraževanju in usposabljanju odraslih (zaposlenih) in strokovnjakov menedžerjev oziroma drugih izvajalcev v vlogi menedžmenta človeških virov. Na ravni strokovne službe dejavnosti za razvoj zajemajo oblikovanje programov, načrtovanje usposabljanja in izobraževanja ter njuno organizacijo, navezovanje stikov in izbiro zunanjih izvajalcev, vrednotenje učinkov izobraževanja, lahko pa tudi vodenje in izpeljavo celotnega procesa. Svetovalci v izobraževanju in usposabljanju so menedžmentu človeških virov lahko dragocena strokovna opora in partnerji pri oblikovanju strategij za usposabljanje in izobraževanje, ki na temelju individualnih potreb pripomorejo $\mathrm{k}$ oblikovanju poslovnih procesov in razvoju organizacije prilagojenih programov usposabljanja in izobraževanja. (Kohont, 2019, str. 41-42)

Ko se podjetje širi s produkti, storitvami ali projekti in potrebuje za uspešno izvedbo čim več primerno usposobljenega kadra, je vloga izobraževanja dvojna: skrb za organizacijsko kulturo ter krepitev zmogljivosti in kompetenc. V primeru prvega je potrebno večje število novo zaposlenim predstaviti kulturo podjetja, vrednote podjetja in organizacijsko delovanje (kar pri manjših podjetjih in manjšem zaposlovanju poteka dosti bolj organsko), za optimalno vključevanje v podjetje ob prihodu novo zaposlenega. Hkrati je treba, v primeru pomanjkanja 
primerno usposobljenih kadrov, po zaposlitvi novih sodelavcev, poskrbeti za primerno strokovno-specifično usposobljenost skozi interna in eksterna izobraževanja. To še posebej velja za podjetja, ki se ukvarjajo z zelo mikro-specifičnimi področji in tako še težje pridobijo kadre, ki so »job-fit«, neposredno ob prihodu iz izobraževalnega sistema. Strokovno-specifično je tako potrebno usposobiti nove kadre, razvijati pa je treba tudi dlje časa zaposlene, saj se pojavijo potrebe po novem znanju. Pri združevanju novo zaposlenih in obstoječe zaposlenih ima velik pomen tudi medsebojni prenos znanja in medgeneracijsko sodelovanje, saj se tako znanje in kompetence ne izgubljajo, temveč krepijo, spodbuja pa se tudi kolektivna zavest. Stanje dobrega počutja se najbolj vidno izraža skozi pozitivno klimo v organizaciji, saj jo ustvarjajo vsi zaposleni. Klima pomeni zaznavo in oceno kakovosti delovnega okolja s strani zaposlenih. (Lešnik, 2008, str. 36)

\subsection{Programi za ohranjanje zdravja dobrega počutja}

So programi ki na nek način promovirajo zdravje na delovnem mestu. Ohranjanje fizičnega in psihičnega zdravja zaposlenih je pomembno, saj zdrav človek lažje obvlada stres kot tisti, ki ima različne zdravstvene težave. Programi vključujejo vse načine, ki posameznikom, skupinam ali organizacijam omogočajo povečanje nadzora nad determinantami njihovega zdravja. Potekajo v obliki delavnic, na katerih se zaposleni naučijo, kako primerno skrbeti za svoje zdravje. V organizacijah, v katerih svoje zaposlene vključujejo v programe za ohranjaje zdravja, menijo, da so takšni programi investicija, ki ima pozitivne finančne učinke. Zaposleni, ki so sposobni učinkovito, premagovati stres, so boljšega zdravja, to pa pomeni manj izostankov zaradi bolezni, večjo participacijo, osebno kompetentnost in večjo produktivnost. (Traven, 2005, str. 93)

Vse večje je prepoznavanje potreb organizacij po resnem jemanju blaginje svojih zaposlenih. Naprednejše organizacije to počnejo, ker se zavedajo, da so njihovi najpomembnejši viri človeški viri. Drugi se šele začenjajo ukvarjati z vprašanji dobrega počutja, vendar postaja vse bolj jasno, da veliko težav na delovnem mestu izhaja iz pomankanja zavezanosti za potrebe njihovih zaposlenih. Vse to lahko povzroči težave na delovnem mestu, kot so stres, trpinčenje, konflikti, zloraba alkohola in drog ter duševne motnje. V nekaterih industrijsko razvitih državah s pomočjo zakonodajnih ukrepov sprejemajo programe, namenjene specifičnim zdravstvenim težavam na delovnem mestu, vse to s ciljem dobrega počutja zaposlenih na delovnem mestu. (Mednarodna organizacija dela, 2020, ods. 3)

\subsection{Andragoško vodenje}

Osebo, ki v izobraževalni organizaciji vodi izobraževanje odraslih, poimenuje zakonodaja organizatorja izobraževanja odraslih, andragoška stroka pa vodjo tega izobraževanja. Sodimo, da je vodenje izobraževanja odraslih dosti več, kot le organiziranje neke dejavnosti, in to bomo v nadaljevanju tudi utemeljevali. Na najvišji hierarhični ravni vodenja izobraževalne organizacije je ravnatelj, direktor. Ta opravlja funkcije pedagoško-andragoškega vodenja organizacije in poslovodne funkcije. V strukturi vodenja je navadno vodja izobraževanja 
odraslih neposredno odgovoren ravnatelju ali direktorju izobraževalne organizacije, ponekod pomočniku ravnatelja. V naši izobraževalni praksi se tu navadno pokažeta dve situaciji, in sicer: za kakšno stopnjo poverjanja nalog (gre za porazdelitev nalog, obveznosti in odgovornosti) se odloča ravnatelj, direktor, in kako je usposobljen vodja izobraževanja odraslih za prevzemanje nalog. Vemo, da je ponekod stopnja zaupanja v sodelavce velika in podrejeni veliko nalog opravijo povsem samostojno. Spet drugod želi vse (ali večino nalog) opraviti ravnatelj, saj ni prepričan, da bodo »drugi znali in zmogli«. Pri tem prihaja v vse večjo časovno stisko. Pričakujemo, da ima vodja izobraževanja odraslih v svoji organizaciji dovolj zaupanja vodstva in lahko popolnoma samostojno opravi temeljne strokovne in organizacijske naloge s tega področja. Res pa je, da morajo biti naloge natančno opredeljene in razmejene. (Velikonja, 2012, str. 10)

Ko preverjamo, kakšno vrsto izobrazbe imajo vodje izobraževanja odraslih v ljudskih univerzah, najdemo zelo pisano paleto izobražencev. Pestrost je tudi v njihovih letih prakse in izkušnjah v izobraževanju odraslih. Tega seveda ne štejemo kot primanjkljaj, pogosto se zlasti v skupnih srečanjih izkaže kot veliko bogastvo, ko udeleženci drug drugega dopolnjujejo in se učijo. Toda vodja izobraževanja odraslih mora poznati posebnosti izobraževanja odraslih, imeti mora ustrezno andragoško izobrazbo, ki je lahko podlaga za njegovo nadaljnje spopolnjevanje na tem področju. $\mathrm{V}$ študiji Kompetenčni pristop $\mathrm{k}$ spopolnjevanju andragoških delavcev (Klemenčič, Možina, Žalec 2009, str. 10-13) so iz razprav v fokusnih skupinah povzeli temeljne naloge v izobraževanju odraslih. To so: ugotavljanje izobraževalnih potreb (v družbi ali pri posamezniku), razvoj ustrezne ponudbe izobraževanja odraslih (vpeljava že sprejetih nacionalnih izobraževalnih programov in razvoj lastne izobraževalne ponudbe. $\mathrm{S}$ tem je povezano tudi izvedbeno kurikularno načrtovanje, prilagajanje formalno sprejetih programov za potrebe odrasle populacije ter spremljanje in vrednotenje izobraževanja. Dejavnost ne more biti zaključena, če ni ovrednotena in niso predlagane (in kasneje vpeljane) izboljšave razvijanje in vzpostavljanje novih učnih okolij. Reševanje globalnih problemov je povezano z učenjem, za obsežnejše naloge pa je potrebno povezovanje in spreminjanje. (Velikonja, 2012, str. 10)

\subsection{Menedžer kot andragoški vodja}

Menedžerjeva skrb za dobro počutje zaposlenih je zelo smiselna. Zaposleni bodo organizaciji služili več kot zgolj dobro le takrat, ko bodo notranje umirjeni in izpopolnjeni. Ob tem Lešnik (2008, str. 66) poudarja, da različne možnosti kot so kovčing, vrhunske delavnice in akademije, ki služijo nadgradnji in uveljavitvi posameznikov skritih potencialov ki mu pomagajo uravnavati njegove vsakodnevne izzive, ter izobraževanja, ki niso neposredno povezana s posameznikovim delom, a močno prispevajo $\mathrm{k}$ subjektivnemu občutenju izpolnitve. To so predvsem osebne terapije, storitve »welness « in delavnice, ki urijo posameznikove diametralne nasprotne veščine od teh ki jih potrebuje v službi. (Lešnik, 2008, str. 66)

V sedanji izobraževalni praksi opravljajo vodje izobraževanja odraslih predvsem organizacijsko in strokovno-razvojno delo, vodstvenega dela je bistveno manj. (Klemenčič, Možina, Žalec, 2009, str. 18) 
Deleži organizacijskih, strokovno-razvojnih in vodstvenih nalog so odvisni od notranje organizacije dela, tudi od števila udeležencev. Pogosto organizacijsko delo preobremeni vodjo izobraževanja in mu otežuje, da bi več časa namenjal strokovnemu in razvojnemu delu. Uspešen vodja izobraževanja odraslih naj torej razvija obe vlogi, upravljavsko in voditeljsko. V tem primeru govorimo o andragoškem vodji in vloga takega vodje je še dodatno obremenjena, saj jo določa tudi vrsta družbenih in kulturnih razmer v okolju. Vodja izobraževanja odraslih mora biti strokovnjak za andragoška vprašanja, vendar hkrati tudi dober organizator dela $\mathrm{v}$ izobraževalni organizaciji. Vendar menimo, da je vodja izobraževanja odraslih vodja v polnem pomenu, zato naj vpliva na vse elemente pedagoško-andragoške dejavnosti. (Velikonja, 2012, str. 11)

Eden od učinkovitih orodij za razvoj menedžerjev je tudi proces kovčinga, kateri pripomore menedžerju k uspešnosti in učinkovitosti vodenja zaposlenih in s tem širi dobro počutje ter odpravlja stres ter s tem doseganje boljših rezultatov tako posameznih zaposlenih kot same organizacije. Stanje dobrega počutja v organizaciji se najbolj vidno izraža skozi pozitivno klimo v organizaciji, saj jo ustvarjajo vsi zaposleni. Klima pomeni zaznavo in oceno kakovosti delovnega okolja s strani zaposlenih. (Lešnik, 2008, str. 36)

V Sloveniji uporabljamo za besedo kovčing tudi drug izraz, vodenje, kjer ima mentor oziroma inštruktor vlogo, da vodi menedžerja ali celoten poslovni tim do samih ugotovitev njihovih izobraževalnih potreb, ter jim jih pomaga uresničiti. Namen kovčinga je pristop k izobraževanju odraslih, katerega cilj je, da pomaga menedžerjem v celoti uresničiti svoje lastne ter življenjske in poslovne cilje in si bodo $\mathrm{s}$ tem pridobili širok obseg intuicije, čustvene inteligence in fleksibilnosti, katere bodo temeljile na tehničnih sposobnostih in spretnostih ter jih bodo maksimalno uporabili za koristi zaposlenih in organizacije. (Čeč, 2006, str.7)

Obstajajo različni programi dobrega počutja, kjer tim izvajalcev izvaja usposabljanje iz oči v oči v obliki delavnic in seminarjev ali pa v obliki aplikacije »Resilience«, katera zagotovi personalizirano orodje, vključno z ocenjevanjem, spletnim učenjem ter sledenjem ciljem. Vse oblike usposabljanja pa so zasnovana tako, da vključi udeležence, jim pomaga obvladati stres, izboljša počutje ter odkriti, kako gojiti pogoje za optimalno delovanje. (The Resilience Institute, 2020, ods. 1-2)

\subsection{Merjenje učinkovitosti izobraževanja}

Pogosto mnenje izobraževalnih institucij je, da je izobraževanje potekalo uspešno, vendar pa se le redki lotijo merjenja te uspešnosti. Če dejansko izobraževalne ustanove ne vedo, ali je bilo izobraževanje uspešno ali ne, ne morejo tega izobraževanja izboljšati. Večina organizacij kar nadaljuje delo po enakih metodah kot v preteklosti, mnogo izobraževalnih institucij meri svojo uspešnost $\mathrm{z}$ anketnimi vprašalniki. Tukaj domnevajo, da je bilo izobraževanje uspešno, ker so udeleženci tako odgovorili na vprašalnik, vendar pa se pri tem pozablja na učne cilje. Po izkušnjah izvajalcev izobraževanja lahko sami izvajalci poskusijo izboljšati učinkovitost izobraževanja samo z ustreznim ugotavljanjem in merjenjem uspešnosti izobraževanja. 
Učinkovit izvajalec izobraževanja se zaveda, da je uspešnost izobraževanja odvisna od njegove dejavnosti v določenih fazah procesa izobraževanja (faza ugotavljanja izobraževalnih potreb, načrtovanje in programiranje izobraževanja, organizacija izobraževanja, izvedba in na koncu vrednotenje). Za vsako fazo procesa izobraževanja si je potrebno vzeti dovolj časa za pripravo. Samo načrtovanje izobraževanja zajema določanje in opisovanje tistega, kar želimo doseči s programom ter določanje in opisovanje načina, kako bomo to dosegli. Izobraževalne potrebe je potrebno raziskovati ves čas, ker se izredno hitro spreminjajo. Nekatere potrebe popolnoma izginejo ali pa se povsem spremenijo. Uspešnost nekega programa izobraževanja se lahko oceni med izobraževanjem ali po končanem izobraževanju. Med izobraževanjem izvajalce zanima, ali so udeleženci dosegli posamezne cilje. Po sami izvedbi izobraževanja se izvajalci srečujejo s časovnim pomanjkanjem evalvacije. Ker so programi običajno zelo obsežni, je večini predavateljev na koncu vsakega programa težko določiti čas, ki naj bi zadostoval za utrjevanje in ponavljanje snovi. Z evalvacijo že izvedenih programov lahko institucija pridobi zelo pomembne informacije, ki jih lahko uporabi kot dopolnitev pri načrtovanju prihodnjih izobraževanj. Formativno ugotavljanje in vrednotenje znanja, spretnosti in kompetenc je usmerjeno predvsem $\mathrm{v}$ učenje in izobraževanje. Temeljni pomen pa je podajanje povratnih informacij kandidatu o njegovi učnih rezultatih. Sumativni prijem pa je usmerjen v učne dosežke in hkrati povezan s poklicnimi ali izobraževalnimi standardi. Poglavitni namen tega tipa vrednotenja je formalno priznavanje učnih dosežkov, izid pa je pridobljena formalna listina. (Mlinar, 2019, str. 162)

Metoda 360 stopinj je v svetu uveljavljeno orodje pri ocenjevanju zaposlenih, ki jo izpeljuje več ocenjevalcev, in sicer podrejeni zaposlenega, njegovi sodelavci, nadrejeni, oceni pa se tudi delavec sam. Izidi uporabljene metode se uporabljajo za načrtovanje in organiziranje specifičnih poti zaposlenih pri njihovem poklicnem razvoju. Metoda pa se najpogosteje uporablja kot razvojno orodje saj ima vlogo formativnega ocenjevanja, katerega temeljni namen je pridobivanje povratne informacije. Je anonimna saj je ocenjevanje zaposlenemu podana le povratna informacija o ugotovljenih močnih in šipkih točkah. (Mlinar, 2019, str. 163)

Kakovost izobraževalne ustanove se določa s štirimi kriteriji (Kotler in Fox, 1995 str. 99):

- doseženi rezultati izobraževalcev,

- izvedba izobraževalnega procesa,

- vodenje institucije,

- sodelovanje institucije z okoljem.

Povratno informacijo o učinkih svojega dela po Kotlerjevem mnenju izvajalci izobraževanj definirajo svoje poslanstvo z odgovori na vprašanja:

- kakšna je naša funkcija $v$ družbi?

- kaj ponujamo?

- komu služimo?

- kaj bomo ponujali?

- $\quad$ kaj moramo ponujati? 
Celovito obvladanje kakovosti je torej z vidika izobraževalne organizacije proces, ki zajema aktivnosti zavestnega odločanja, doseganja in nadziranja ciljev kakovosti v celotni organizaciji. Ne zadeva aktivnosti neposredno $\mathrm{v}$ zvezi s cilji pri ponujanju in izvajanju izobraževalnih storitev, ampak tudi v zvezi s cilji pri nabavi, knjigovodstvu, štipendiranju, nagrajevanju in drugih

Vsa podjetja ponujajo svojim udeležencem izobraževanj svetovanje po končanem izobraževanju. Pri mnogih podjetjih svetovanje izvaja sam predavatelj po končanem izobraževanju. To svetovanje lahko poteka v okviru izobraževalne ustanove, mnogokrat pa poteka po individualnem dogovoru med predavateljem in udeleženci izobraževanj. (Kotler in Fox, 1995 str. 99)

\section{Metoda}

S kvalitativno metodo raziskovanja smo preučili teoretična izhodišča naše raziskave. Podatke smo pridobivali iz različnih člankov in revij na temo izobraževalnih programov za menedžerje dobrega počutja. Pregledali smo obstoječo literaturo na raziskovalno temo znotraj kriterija raziskave EU, ZDA in Slovenije.

Pregled literature je temeljil na konceptualni strukturi, ki križno preveri izobraževalne programe, medijske formate, metode, pristope in strategije poučevanja menedžerjev. Podatke smo pridobivali s pomočjo iskanja člankov, objavljenih $\mathrm{v}$ indeksiranih revijah, nacionalnih poročilih kot tudi s pomočjo Google Učenjak in ostalih spletnih strani. Literatura se je nanašala na izobraževalne programe za menedžerje dobrega počutja oziroma sorodne teme, kjer so se upoštevale mešane metode, tako kvantitativne kot kvalitativne metode ter pregledni članki. Z iskanjem po ključnih besedah smo poiskali 57 člankov in spletnih strani, kjer se je izključila vsa literatura, katera se ne nanaša na odraslo populacijo oziroma katera se nanaša na izobraževalni program za otroke ter same metode poučevanja otrok ter katera se ni nanašala na kriterij raziskave EU, ZDA in Slovenija. Po pregledu in izločanju člankov in spletnih strani, ki niso zadostovala kriterijem raziskave smo jih izmed 57, izbrali 38 člankov in spletnih strani.

Za iskanje vsebin za raziskavo smo na podlagi zastavljenih raziskovalnih vprašanj uporabili naslednje ključne besede, katere so prikazane v tabeli 1. 
Tabela 1. Raziskovalna vprašanja s ključnimi besedami

\begin{tabular}{|c|c|c|c|}
\hline \multicolumn{2}{|c|}{ Raziskovalno vprašanje: } & \multicolumn{2}{|c|}{ Ključna beseda: } \\
\hline slovensko & angleško & slovenska & angleška \\
\hline $\begin{array}{l}\text { Kateri so najbolj } \\
\text { optimalni medijski } \\
\text { formati za učno vsebino } \\
\text { za ciljno skupino } \\
\text { (menedžerji dobrega } \\
\text { počutja)? }\end{array}$ & $\begin{array}{l}\text { What are the most } \\
\text { appropriate media } \\
\text { formats for learning } \\
\text { content for target } \\
\text { groups? }\end{array}$ & $\begin{array}{l}\text { Medijski format }+ \\
\text { menedžer }+ \text { dobro } \\
\text { počutje }\end{array}$ & $\begin{array}{l}\text { Media format + manager } \\
+ \text { well-being }\end{array}$ \\
\hline $\begin{array}{l}\text { Katero ogrodje } \\
\text { ocenjevanja bi bila } \\
\text { najbolj primerna za } \\
\text { merjenje izidov? }\end{array}$ & $\begin{array}{l}\text { What type of assessment } \\
\text { framework would be } \\
\text { most appropriate to } \\
\text { facilitate the } \\
\text { measurement of } \\
\text { attainment? }\end{array}$ & $\begin{array}{l}\text { Ocenjevanje + menedžer } \\
+ \text { dobro počutje }\end{array}$ & $\begin{array}{l}\text { Grading }+ \text { manager }+ \\
\text { well-being } \\
\text { Type }+ \text { assessment }+ \\
\text { framework }+ \\
\text { measurement }\end{array}$ \\
\hline $\begin{array}{l}\text { Katere vrste } \\
\text { pedagoške/andragoške } \\
\text { pomoči so potrebna, da } \\
\text { sodelujejo udeleženci } \\
\text { (menedžerji dobrega } \\
\text { počutja) v učno vsebino? } \\
\text { »nadaljevanje« }\end{array}$ & $\begin{array}{l}\text { What types of pedagogic } \\
\text { supports are needed to } \\
\text { facilitate the involvement } \\
\text { of participants (work } \\
\text { well-being managers) } \\
\text { into the programme } \\
\text { framework? }\end{array}$ & $\begin{array}{l}\text { Andragoško + } \\
\text { izobraževanje + } \\
\text { menedžer + dobro } \\
\text { počutje }\end{array}$ & $\begin{array}{l}\text { Curriculum program }+ \\
\text { manager }+ \text { well-being }\end{array}$ \\
\hline $\begin{array}{l}\text { Katere so najbolj } \\
\text { primerna učne } \\
\text { metodologije } \\
\text { (poučevanja } \\
\text { »nadaljevanje« }\end{array}$ & $\begin{array}{l}\text { What are the most } \\
\text { appropriate teaching and } \\
\text { learning methodologies } \\
\text { for work well-being } \\
\text { managers? }\end{array}$ & $\begin{array}{l}\text { Metodologija }+ \\
\text { menedžer }+ \text { dobro } \\
\text { počutje }\end{array}$ & $\begin{array}{l}\text { Training + methods }+ \\
\text { manager + well-being }\end{array}$ \\
\hline $\begin{array}{l}\text { in učenje) za menedžerje } \\
\text { dobrega počutja? }\end{array}$ & & & \\
\hline
\end{tabular}

\section{Rezultati}

\subsection{Rezultati raziskav EU in ZDA}

V ZDA obstajajo različna svetovalna podjetja, katera krepijo in navdihujejo vodilne zaposlene oziroma menedžerje, da le ti postanejo učinkovitejši pri svojem delu ter krepijo in širijo delovno kulturo ter poslanstvo organizacije med svoje zaposlene. Delo poteka v okviru odnosov, kar pomeni stalno sodelovanje in spremljanje organizacije ter razpravljanje o novih idejah. Nudijo programe od strateškega vodenja, kovčinga za menedžerje, do »teambuildinga« ter razvoja človeških virov. (OPG, 2017, ods. 1)

Obstajajo tudi različne »wellness « rešitve, ki tudi pripomorejo k dobremu počutju zaposlenih ter na podlagi preprostih aplikacij ponuja kratke dnevne lekcije, kot so: kajenje, obvladovanje telesne teže, obvladovanje stresa, do spopadanja s kroničnimi boleznimi. (2Morrow, Inc., 2017, ods. 1-3) 
V ZDA torej obstajajo tako izobraževalni programi v sami organizaciji, do spletnih seminarjev, e-izobraževanj ter različnih aplikacij preko katerih se menedžerji organizacij izobražujejo, da postanejo kompatibilni za širjenje in spodbujanje dobrega počutja med svojimi zaposlenimi.

Doktor Steve Aldana (2020, 2. januar, str. 1) je navedel sedem najpomembnejših razlogov, kako ponuditi dobro počutje zaposlenim pri delu:

Programi dobrega počutja izboljšajo vedenje zdravja zaposlenih: bistvo izobraževalnih programov dobrega počutja je sprememba vedenja. Vse to se doseže le s pravilnim izobraževanjem, spretnostmi, orodji, motivacijo in socialno podporo. To pa vodi k manjšemu tveganju glede zdravja in posledično manjšemu nastanku kroničnih bolezni. Večina študij dobrega počutja kaže, da zaposleni, kateri jedo bolj zdravo hrano, jedo manjše porcije, pogosteje telovadijo, manj kadijo, ne pijejo prekomerno, precej bolje obvladujejo stres, depresijo ter si s tem izboljšujejo zadovoljstvo življenja. Kot pravi Soeren Mattke (2013, ods. 31), vodilni avtor poročila Rand, ugotavljajo, da lahko programi dobrega počutja na delovnem mestu pomagajo omejiti sedanjo epidemijo bolezni, povezanih z življenjskim slogom, ki so glavni dejavniki za prezgodnje obolelosti in umrljivosti ter stroški zdravstvene oskrbe v ZDA. (Aldana, 2020, str. 1)

Program dobrega počutja zmanjšuje povečana zdravstvena tveganja: temelj dobrega počutja, mora biti osredotočenost za pomoč zaposlenim pri sprejemanju zdravega vedenja, kot na primer jesti in telovaditi. Pred nekaj leti je bilo izvedeno klinično preizkušanje, ki je ljudem pomagalo izboljšati prehrano in telesne aktivnosti ter s tem povzročilo izboljšanje zdravstvenih tveganj v samo šestih tednih. (Aldana, 2020, str. 1)

Slabi programi dobrega počutja: pri vseh teh programih, pa obstaja edina slabost in sicer epidemija debelosti, katero povzročajo številni kulturni dejavniki. Vse raziskave kažejo, da je pomoč ljudem pri zmanjševanju holesterola v krvi, krvnega tlaka in glukoze učinkovito, le ta učinkovitost pa ni dosežena pri zaposlenih oziroma pomoči zaposlenim pri hujšanju. Vse to pa je posledica nezdrave kulture pri večini ljudeh ZDA in tudi v industrializiranem svetu. Če povzamemo, torej programi dobrega počutja ne bodo pomagali doseči zdrave telesne teže, vendar bodo pomagali, da zaposleni prenehajo pridobivati na teži. (Aldana, 2020, str. 1)

Program dobrega počutja zmanjšuje stroške zdravstvene oskrbe: obstaja veliko študij raziskav, kjer so se pregledovali finančni vplivi programov dobrega počutja. Raziskovalci s Harvarda so med 22 različnimi študijami, preučile programe dobrega počutja in zdravstvenih stroškov, kjer so ugotovili, da so za vsak dolar, ki je bil namenjen programu, prihranili 3,27 dolarja, zaradi manjših stroškov zdravstvenega varstva. V letu 2014 so raziskovalci ocenili vpliv programa dobrega počutja »WellSteps «, kjer so na določenem delovnem mestu po štirih letih, za vsak vložen dolar v program, prihranili 3,3 dolarja zaradi manjših stroškov zdravstvenega varstva. (Aldana, 2020, str. 1) 
Programi dobrega počutja izboljšajo storilnost: slabo produktivnost zaposlenih opredeljujemo kot fizično delo v službi, kar imenujemo prezentizem (pomeni prisotnost na delovnem mestu, kljub delavčevemu slabemu počutju, bolezni ali motečim dejavnikom iz osebnega življenja - wikipedija), kjer se ocenjuje, da stroški povezani s prezentizmom zaradi slabega zdravstvenega stanja zaposlenih presegajo vsaj 2 do 3 krat večje neposredne stroške zdravstvenega varstva. Raziskava je pokazala, da zaposleni, kateri kadijo, ne jedo zdravo ali redno ne telovadijo imajo povečano stopnjo prisotnosti prezentizma. Tako, da lahko povzamemo, da bodo programi za dobro počutje, ki se osredotočajo za pomoč zaposlenim do dobrega zdravstvenega stanja, pripomogli oziroma vplivali tudi na boljšo produktivnost zaposlenih. (Aldana, 2020, str. 1)

Programi dobrega počutja lahko zmanjšajo absentizem: obstaja več 50 prispevkov na to temo povezav programov dobrega počutja na delovnem mestu in zmanjšanju odsotnosti zaposlenih. Raziskava je pokazala, da delovna mesta s celovitim programom dobrega počutja doživijo manjšo odsotnost zaposlenih iz različnih razlogov (Aldana, 2020, str. 1):

- Pri zaposlenih z dobrim zdravstvenim počutjem.

- Pri zaposlenih, ki lahko obvladujejo stres.

- Pri zaposlenih z dobrim krvnim tlakom, holesterolom in sladkorjem.

- Pri zaposlenih, ki nimajo prekomerne telesne teže.

Programi dobrega počutja, lahko pomagajo izboljšati zaposlovanje in zadrževanje zaposlenih: na to temo ni objavljenih veliko raziskav, kateri bi dokazovali, da programi dobrega počutja lahko vplivajo na sposobnost izboljšanega zaposlovanja in zadrževanja zaposlenih v organizaciji. Primer iz prakse, kjer ob zaposlitvi pri Microsoftu dobiš paket njihovih ugodnosti od brezplačnega članstva $\mathrm{v}$ telovadnici do zdravstvene ambulante. Tu mora biti predvsem zavedanje vsake organizacije, da so zaposleni eden najpomembnejših virov, katere je potrebno stalno negovati in se jim pokaže, da jim je mar za zaposlene. (Aldana, 2020, str. 1)

Programi dobrega počutja gradijo in pomagajo vzdrževati visoko moralo zaposlenih: morala zaposlenih je velik dejavnik uspeha ali neuspeha mnogih organizacij, dober program dobrega počutja pa lahko pomaga zaposlenim, da so srečni in zdravi. Maslowa hierarhija potreb prikazuje potrebe, ki jih imamo vsi ljudje in najpomembnejše so na dnu piramide (hrana, voda, socialne potrebe), kjer brez teh osnovnih potreb v življenju ne moremo delovati. Torej, če ponudite program dobrega počutja svojim zaposlenim, jim s tem sporočate, da jih spoštujete, jim zaupate in jim želite pomagati, da bodo uspešni v življenju. Visoka morala zaposlenih je takrat, ko jim je dovoljeno, da so kreativni, rešujejo težave, se počutijo varne in cenjene. Razvijajo svojo samozavest, dosegajo osebne cilje in želje, ter so srečni ko imajo občutek nadzora nad svojim življenjem in zdravjem. (Aldana, 2020, str. 1)

V ZDA se je o preobremenjenosti zaposlenih prvič pisalo leta 2014. Čeprav ta beseda preobremenjenost zaposlenih ni nekaj novega, ampak je novo tempo poslovanja organizacija. (Schwartz, Agarwal, Bersin, \& Volini, 2014, ods. 3) 
Študija je pokazala, da se več kot $40 \%$ zaposlenih na delovnem mestu srečuje z velikim stresom, kar je posledica vpliva na njihovo produktivnost, zdravje in razmere v družini.

Z eksplozijo digitalne blaginje je bilo v zadnjih dveh letih v ZDA vloženih nekaj milijard dolarjev tveganega kapitala, kar je posledično ustvarilo poplavo spletnih videoposnetkov, aplikacij in orodij za pomoč ocenjevanja, spremljanja in izboljševanja zdravja zaposlenih. (Deloitte Insights, 2018, ods. 4)

Programi dobrega počutja so postali strateška prednostna naloga, kjer se je že pred desetletji začelo trgovanje $\mathrm{z}$ različnimi podjetniškimi »wellness« programi, s poudarkom na fizičnem zdravju in varnosti zaposlenih. Dandanes, pa se je definicija dobrega počutja dramatično razširila in vključuje vrsto programov, ki poleg varovanja zdravja zaposlenih vključuje tudi aktivno izboljševanje uspešnosti ter socialno in čustveno počutje. Vsi ti inovativni programi in orodja vključujejo od programov oziroma orodij za finančno počutje, duševno zdravje, zdravo prehrano in telovadbo, spanje in obvladovanje stresa do spremembe $\mathrm{v}$ kulturi in vedenjskem vzorcu.

Kot navaja (Deloitte Insights, 2018, ods. 6) je bilo v te programe (programi, ocenjevanja, izobraževanja, aplikacije,...), v ZDA, vloženih 8 milijard dolarjev in se pričakuje, da bo do leta 2021 vloženo 11,3 milijarde dolarjev.

Na podlagi velikega povpraševanja v ZDA po programih za dobro počutje, so številni začeli ponujati različne platforme, ki delodajalcem omogočajo široko paleto rešitev za dobro počutje zaposlenih preko integriranih aplikacij. Nekateri ponujajo aplikacijo za zaposlene, katera se uporablja tako pogosto kot Facebook, kjer so aktivni uporabniki 65\% bolj angažirani in imajo $32 \%$ nižjo stopnjo prometa (turnover rates) in prinašajo $9 \%$ večjo produktivnost. (Bersin, 2017, ods. 15)

Tudi v EU je ena ključnih nalog spodbujanje visokih delovnih pogojev na področju zdravja in dobrega počutja pri delu zaposlenih. S tem želi direktiva EU o ukrepih za izboljšanje varnosti in zdravja pri delu zaščititi delavce na delovnem mestu ter spodbuditi pravice le teh. Strateški okvir Evropske komisije za zdravje in varnost pri delu 2014-2020 določa pomembne izzive in cilje za članice EU. Predvsem vključuje izboljševanje zdravstvenih in varnostnih pravil, preprečevanje poklicnih bolezni ter vprašanja v zvezi s starajočo se delovno silo. (Eurofond, 2020, ods. 2)

Pravijo, da se dobro počutje na delovnem mestu nanaša na vse vidike delovnega življenja, tako od kakovosti in varnosti, do same organizacije dela. Cilj oziroma ukrepi za dobro počutje na delovnem mestu zaposlenega je predvsem skrb, da so zaposleni varni, zdravi, zadovoljni in angažirani pri delu, saj je dobro počutje zaposlenih ključni dejavnik za dolgoročno učinkovitost organizacije. 
Žižek et al. (2013, str. 1-31), pravijo, da tako stres kot tudi dobro počutje nista namenjena samemu sebi, ampak ljudem. Po podatkih iz leta 2005 je bila druga najpogosteje prijavljena težava stres povezan $\mathrm{z}$ delom in je šlo za kar 22\% vseh zaposlenih v Evropski uniji.

V različnih organizacijah po EU obstaja kar nekaj modelov dobre prakse za dobro počutje zaposlenih. V organizaciji QVC je bil njihov posledični cilj predvsem usposobiti oziroma seznaniti menedžerje $\mathrm{z}$ orodji, znanjem za prepoznavanje potencialnih znakov stresa in preprečevanjem le - tega. Želeli so, da menedžerji razumejo poudarek dobrega počutja zaposlenih in da bi se s programom dobrega počutja osredotočili na zaposlene. V program so vključili celotno višje vodstvo, katerega so seznanili z vsemi podatki in prednostmi. Po predstavitvi in uvedbi programa je bilo zaznati, da več kot $40 \%$ zaposlenih verjame, da ima ta program pozitiven vpliv na njihovo življenje izven službe in več kot $50 \%$ zaposlenih jih verjame, da ima ta program pozitiven vpliv na njihovo poklicno življenje ter $70 \%$ zaposlenih jih meni, da je program vplival na njihovo zavedanje o pomenu zdravja. (Žižek et al., 2013, str. 64-65)

V nizozemskem finančno zavarovalnem podjetju AGIS Zorverzekeringen, je bil zastavljen zdravstveni projekt za vseh 1500 sodelavcev in sodelavk. Med zadanimi cilji je bil tudi cilj ohranjanja fizičnega in duševnega zdravja na delovnem mestu, ter za ustvarjanje zdravih delovnih mest, ki bi pozitivno vplivali na dobro počutje in razvoj zaposlenih. Razvili so tako imenovani Healt Behaviour Model, s katerim je že v naprej zaznati duševne težave zaposlenih in jim s tem modelom poskušajo ponovno pridobiti duševno vzdržljivost. Model vsebuje vrsto ukrepov, ki so prilagojeni stopnji in časovnemu obdobju duševnih težav (mentorstvo, treningi, gibalni programi). Vsako leto se izdela katalog ponujenih aktivnosti, ki je dostopen vsem zaposlenim, poleg spletne strani z informacijami in prireditvami, ter po potrebi so na razpolago tudi osebni razgovori. Vsako leto, vsak zaposleni izpolni vprašalnik o zdravju, na podlagi katerega se ponujeni zdravstveni program ovrednoti. Mesečno se na nivoju vodstva razpravlja o zdravju zaposlenih, tako so v zadnjih 10 letih znižali odsotnost z dela z $9 \%$ na $2,5 \%$ ter s tem povišali produktivnost, delovno zmogljivost in dobro počutje zaposlenih. (Žižek et al., 2013, str. 68-69)

V EU obstaja dosti modelov oziroma pristopov, ki imajo pomembno vlogo pri izboljšanju dobrega počutja zaposlenih. Primer model zahtev in nadzora (nem. Anforderungs-KontrollModell) opisuje, da ima velika mera nadzora oziroma možnost soodločanja, pozitivne zdravstvene učinke. Model ravnovesja med počitkom in obremenitvami (nem. ErholungsBeanspruchung-Balance) se ukvarja z razlogi za stres, ki obravnava predvsem interakcijo med počitkom in obremenitvami.

Po EU deluje več tako imenovanih startup podjetij, ki izboljšujejo počutje zaposlenih z različnimi orodji, od spletnih platform, mobilnih tržnic, aplikacij in programskih oprem. Ta podjetja nudijo zaposlenim preprečiti njihovo lastno izgorelost, ter delodajalcem vpogled v izgradnjo srečnejše in bolj produktivne delovne sile. Drugi ponujajo mobilno tržnico za anonimno svetovanje, kjer z aplikacijo povezujejo ljudi, kateri potrebujejo pogovorno podporo, 
ter delodajalcem ustrezne pogoje za povečanje dobrega počutja njihovih zaposlenih. Drugi spet s pomočjo aplikacije predstavljajo vsebine in tehnike različnih strok z dokazanimi znanstvenimi in psihofizičnimi koristmi od joge, pilatesa in premišljenosti s preprostimi vajami, primernih za vsakogar. (EU-Startups, 2019, str. 1)

\subsection{Rezultati raziskav Slovenija}

Za dobro poznavanje zaposlenih v Sloveniji je poleg splošnih značilnosti treba poznati tudi podatke o njihovem vseživljenjskem učenju. Zaradi spremenjenih razmer na trgu je nenehno izobraževanje in učenje tudi v odrasli dobi postala stalnica in nuja. Vseživljenjsko učenje je za posameznika in družbo ter državo poglavitnega pomena za kakovosten razvoj. Znanje in spretnost zaposlenih so temelj zaposljivosti, blaginje in konkurenčnosti poslovnega sektorja. (Čelebič, 2018 str. 3)

Podatki raziskave PIAAC za Slovenijo so pokazali, da so slovenski dosežki odraslih nižji od povprečja OECD: približno eden od štirih odraslih ima spretnosti na nižjih ravneh. To v številki pomeni 476.000 odraslih in od teh jih bo moralo vsaj še 250.000 konkurirati na trgu dela naslednjih 10 let. V naslednjih letih pa še 140.000 delež odraslih, ki so dosegli najvišjo raven pri posameznih spretnostih, ne presegajo 10\%. Slovenija je v strategijo za razvoj 2030 zapisala, da je med poglavitnimi cilji doseganje kakovostnega življenja za vse v Sloveniji pomembno učenje skozi vse življenje. Znanje in spretnosti so postavljene v ospredje kot temeljni pogoj za kakovostno delo in družbeno blaginjo. Poudarjeno je, da bomo postavljene strateške cilje lahko dosegali z vseživljenjskem učenjem in usposabljanjem kot vrednotama, ki krepita ustvarjalnost, inovativnost, kritično razmišljanje, odgovornost in podjetništvo, ter z uvrstitvijo teh vsebin v programe izobraževanja na vseh ravneh. Ob teh ciljih pa ne moremo prezreti podatkov, ki še vedno kažejo, da novo znanje in spretnosti niso enakopravno dostopni vsem. (Vilič Klenovšek, 2019, str. 10-11)

Med izobraževalnimi centri v podjetjih obstajajo velike razlike. Nekateri centri so zelo razviti (primer izobraževalnega centra podjetja Krka iz Novega mesta ali podjetja Gorenje iz Velenja), kajti pri njih deluje ogromno strokovnjakov, statusno pa so tudi opredeljeni kot izobraževalni centri. Drugo vrsto predstavljajo izobraževalne dejavnosti v okviru kadrovskih služb. Običajno je tukaj zaposlen le eden delavec. Njihova značilnost je, da izvajajo pretežno strokovno izpopolnjevanje za skupino podjetij, v okviru katerih so nastali. Centri pretežno opravljajo strokovno izobraževanje in izpopolnjevanje za podjetje oz. skupino podjetij. Deloma izobražujejo za prvi poklic, prekvalifikacijo, za prehod v delo, usposabljajo vodstveni kader, nekateri pa izvajajo tudi računalniške in jezikovne tečaje. (Krek, 1997, str. 301)

Centri, ki so se razvili v okviru Gospodarske zbornice Slovenije, delujejo danes kot samostojne specializirane izobraževalne organizacije. Delujejo na ozemlju celotne Slovenije in so namenjeni izpopolnjevanju strokovnega vodilnega kadra. Gospodarska zbornica Slovenije tudi organizira posvete in delavnice dobrega počutja katerega skozi projekt NAPREJ sofinancira Republika Slovenija iz Evropskega socialnega sklada. Na posvetu menedžerje seznanijo s 
koncepti dobrega počutja in dimenzij, ki ga sestavljajo, psihosocialne dejavnike tveganja, posledice slabega počutja $\mathrm{v}$ delovnem okolju s poudarkom na vplivih in duševnemu zdravju. Pri zasebnih izobraževalnih organizacijah, gre predvsem za organizacije, ki so nastale nedavno nazaj. Področje njihovega dela je zelo raznoliko: od jezikovnih programov, programov strokovnega izpopolnjevanja in usposabljanja za delo, do programov splošnega neformalnega izobraževanja. (Krek, 1997, str. 301)

V Sloveniji je se z izobraževanjem kadra za bodoče menedžerje dobrega počutja ukvarja fakulteta za menedžment v Mariboru, kjer se študentje usposabljajo iz programov dobrega počutja in dvig kakovosti življenja. Izobraževanje dobrega počutja tudi izvaja podjetje Gotta Nova kateri se ukvarjajo z kovčingom in mehkimi veščinami ter z duševnim, duhovnim in mentalnim velnesom. Izobraževanja organizirana $v$ okviru gospodarske zbornice Slovenije. Delavnice organizira tudi javni štipendijski sklad Republike Slovenije, kjer organizirajo Welbing Menedžment, kjer udeležence ozaveščajo o pomenu dobrega počutja na delovnem mestu. Vse več je novih menedžerskih izobraževanj. Z novimi izobraževanji se uveljavljajo mestni menedžerji katerih skrb je dobro počutje prebivalcev mest. Mestni menedžerji imajo kompetence za upravljanje mestnih središč. Zavedati se je potrebno, da dobro počutje oziroma kvalitetno življenje prebivalcev $\mathrm{v}$ mestih bistveno premore $\mathrm{k}$ večji storilnosti na njihovih delovni mestih.

Izobraževanja se oglašujejo preko revij kot je HRM kjer je strokovna revija za vodenje in razvoj ljudi pri delu, seznanja $\mathrm{z}$ novostmi in aktualnimi tematikami, trendi in razvojem na področju vodenja, upravljanja in razvoja ljudi, prav tako pa v reviji predstavljajo tudi domače in tuje primere dobre prakse. Prispevke pripravljajo priznani tuji in domači strokovnjaki (HR\&M, 2020, odst. 1).

V Sloveniji se izvajajo predvsem nekajdnevne delavnice dobrega počutja na katerih sodelujejo menedžerji. Na delavnicah se udeleženci seznanijo o tem kaj je stres, kako vpliva na komunikacijo, kaj se dogaja s posamezniki, ko so pod stresom, kako se odzivajo nanje, ter kateri so temeljni koraki za obvladovanje stresa. Poleg se še seznanijo, kakšen je pomen dihanja in sproščanja pri obvladovanju stresa, spoznajo dihalne vaje in vaje popolne relaksacije, vire kroničnega izčrpavanja in vire moči, načine ozaveščanja in obvladovanje čustev, tehnike uspešnega upravljanja $\mathrm{s}$ časom in ustvarjalnega reševanja problemov ter pomen misli posameznika in proaktivnega vedenja. Namen delavnic je ozavestiti menedžerje v katerih situacijah posamezniki doživljajo stres, odkriti možnosti, kako lahko učinkovito pomagajo zaposlenim, ter spodbujati zaposlene k razmišljanju kako preprečiti izgorevanje na delovnem mestu.

Kovčing je v Sloveniji že kar nekaj časa prisoten, ki se od ostalih programov razlikuje po uporabi komunikacijskih veščin neuro lingvističnega programiranja, ki predstavlja eno najbolj učinkovitih tehnik komuniciranja. Izvajajo ga mednarodno certificirani NLP kovči, ki so strokovnjaki za kovčing in NLP. Organizacija, ki se v Sloveniji ukvarja z izobraževanjem mednarodno certificiranih NLP kovčev je Glotta Nova, ki usposablja vodje za uporabo 
kovčinga pri vodenju, ter izvaja kovčing kot proces, v katerega se vključujejo vodje, drugi zaposleni ali timi. Poleg NLP kovčinag se menedžeri še poslužujejo NLP praktik kateri je namenjen za izobraževanje izboljšanja komunikacijskih veščin. Ima pozitivni vpliv na osebnostni, profesionalni in strokovni razvoj posameznika. NLP mojster praktik pa je nadgradnja NLP praktika, ki udeležencem omogoča da postanejo eksperti pri doseganju rezultatov v poslovnem svetu. (Velnes.si, 2020, ods. 2)

$»$ Wellness « programi, je program, kjer je glavni cilj promocija zdravega življenjskega sloga in izboljšanje zdravja zaposlenih, prav zato so namenjeni vsem zaposlenim, ne samo tistim z zdravstvenimi težavami. Slednji s spremembo življenjskega sloga težave odpravijo oziroma jih vsaj uspešno obvladujejo, zdravi zaposleni pa z ustreznim življenjskim slogom svoje zdravje krepijo in zmanjšajo stopnjo tveganja za razvoj kroničnih nenalezljivih bolezni. V Sloveniji se tudi menedžerji zavedajo, kako pomembno je, da imajo delovne organizacije zdrave in zadovoljne zaposlene. Cilj »wellness« programa je, da skrbi za zdravje in dobro počutje zaposlenih. Kot smo že omenili, ima od tega koristi delodajalec, saj so njegovi zaposleni bolj zdravi in zadovoljni, s tem pa se zmanjšajo stroški absentizma, prezentizma in fluktuacije, povečata pa se produktivnost in pripadnost zaposlenih.

Angleška beseda »Wellness«, je sestavljena iz besed »well-being«, kar pomeni dobro počutje, in »fitness", kar označuje stanje dobrega zdravja in počutja, vse to pa je rezultat telesne dejavnosti in pravilne prehrane. $Z$ »wellness « programom veliko pridobijo tudi zaposleni. »Wellness « progami običajno vključujejo promocijo zdravega sloga življenja, izobraževanja za zaposlene, zdravstvene monitoringe in podobno. Vse te aktivnosti pripomorejo $k$ temu, da so zaposleni ozaveščeni in poučeni o zdravem življenjskem slogu. Veliko se jih odloči za spremembo življenjskega sloga in k temu spodbudijo še ostale sodelavce ali svoje družinske člane. (Skupina IRI, 2017, ods. 1-9)

Korporacijski »wellness« ponuja nov integriran športno-medicinski pristop pri upravljanju s človeškimi viri, ki zagotavlja dolgoročno uspešnejše in produktivnejše delo, zniža stroške, ki nastajajo zaradi odsotnosti zaposlenih z dela, poveča motivacijo zaposlenih in spodbuja zdrav način življenja, kar je $v$ današnji družbi in načinu življenja še posebej pomembno. Z razvojem civilizacije, urbanizacije in mehanizacije se je povečalo število nekaterih bolezni, kot so zvišan krvni pritisk, srčni infarkt, sladkorna bolezen, povišan odstotek maščob v krvi, debelost, nervoze. Boleznim sodobne civilizacije pravijo nekateri kar bolezni pomanjkanja gibanja ali bolezni sedečih poklicev. S primerno načrtovanim obsegom in intenzivnostjo lahko razvijamo in vzdržujemo človekove fiziološke in motorične sposobnosti, zvišujemo biološko odpornost v smislu zdravstvenega stanja, razvijamo moralno voljne kvalitete, omogočamo obnavljanje življenjske energije in dobrega počutja po velikih psihičnih obremenitvah. (Koren Sports Group, 2010, str. 1) 


\subsection{Skupni rezultati}

$\mathrm{Na}$ podlagi zastavljenih raziskovalnih vprašanj, smo v tabeli 2. prikazali nekaj ključnih rezultatov in ugotovitev, katere smo pridobili iz različnih člankov in revij glede na raziskovalno temo.

Tabela 2. Prikaz skupnih rezultatov EU in ZDA ter Slovenije

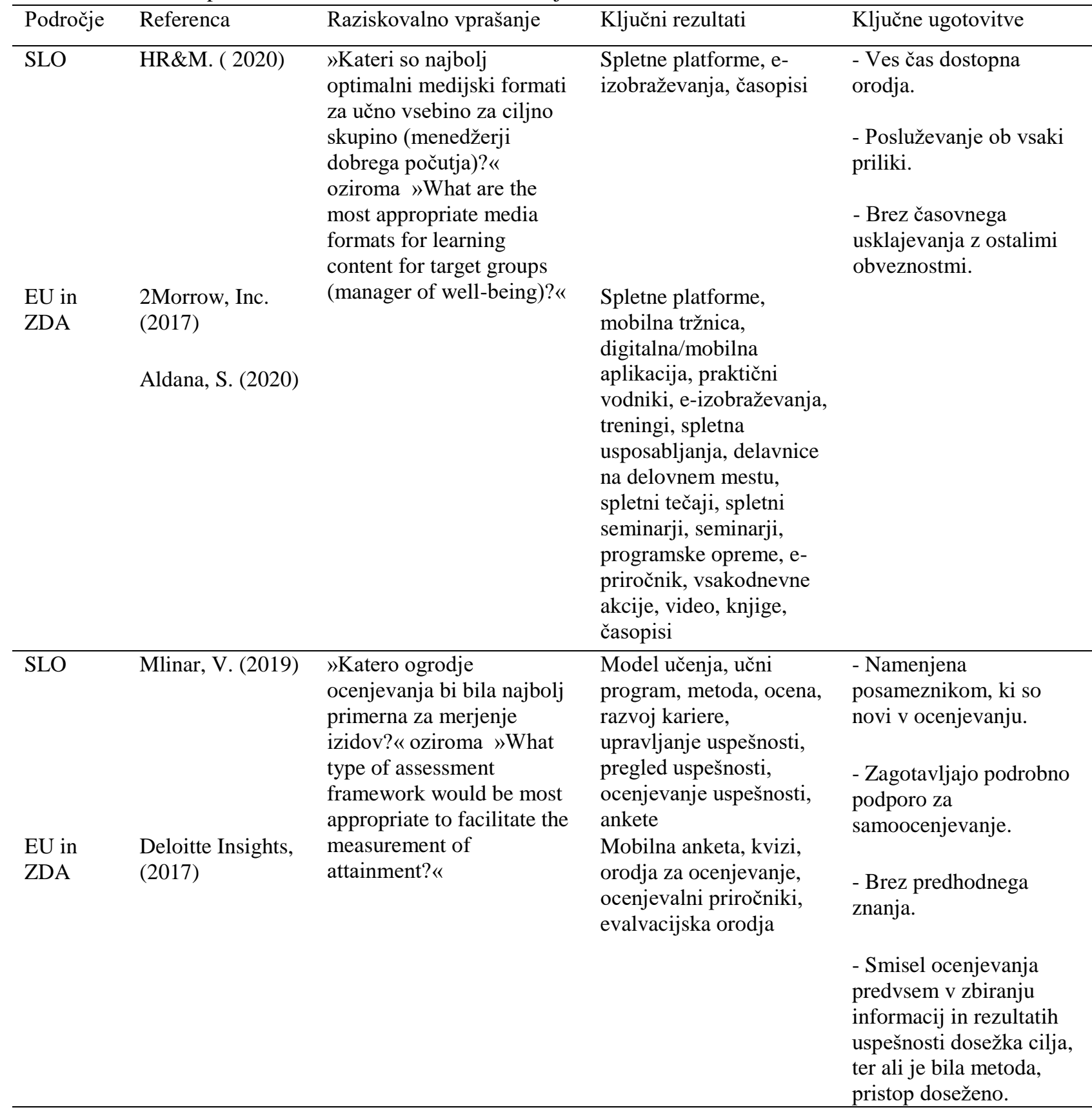


nadaljevanje «

\begin{tabular}{|c|c|c|c|c|}
\hline $\begin{array}{l}\text { EU in } \\
\text { ZDA }\end{array}$ & $\begin{array}{l}\text { Žižek et al., } \\
(2017) \\
\text { IBISWorld. } \\
(2016)\end{array}$ & $\begin{array}{l}\gg \text { Katere vrste } \\
\text { pedagoške/andragoške } \\
\text { pomoči so potrebna, da } \\
\text { sodelujejo udeleženci } \\
\text { (menedžerji dobrega } \\
\text { počutja) v učno vsebino?« } \\
\text { oziroma »What types of } \\
\text { pedagogic supports are } \\
\text { needed to facilitate the } \\
\text { involvement of participants } \\
\text { (work well-being } \\
\text { managers) into the } \\
\text { programme framework?« }\end{array}$ & $\begin{array}{l}\text { Delavnice na temo } \\
\text { dobrega počutja, tečaji } \\
\text { za menedžerje, spletno } \\
\text { učenje, učenje na } \\
\text { delovnem mestu, } \\
\text { izobraževanje in } \\
\text { mentorstvo, } \\
\text { organizacijsko učenje }\end{array}$ & $\begin{array}{l}\text { - Prevladuje predvsem } \\
\text { pomoč z } \\
\text { osredotočenostjo na } \\
\text { potrebe in cilje } \\
\text { slušateljev. } \\
\text { - Podprto predvsem z } \\
\text { vsebino c ciljem } \\
\text { izboljšanja razumevanja } \\
\text { in pravilnega } \\
\text { ozaveščanja dobrega } \\
\text { počutja zaposlenih pri } \\
\text { delu. }\end{array}$ \\
\hline $\begin{array}{l}\text { EU in } \\
\text { ZDA }\end{array}$ & $\begin{array}{l}\text { Žižek et al., } \\
(2017) \\
\text { EU-Startups, } \\
(2019)\end{array}$ & $\begin{array}{l}\text { »Katere so najbolj } \\
\text { primerna učne } \\
\text { metodologije (poučevanja } \\
\text { in učenje) za menedžerje } \\
\text { dobrega počutja?« oziroma } \\
\text { »What are the most } \\
\text { appropriate teaching and } \\
\text { learning methodologies for } \\
\text { work well-being } \\
\text { managers?« }\end{array}$ & $\begin{array}{l}\text { Predavanja, seminarji za } \\
\text { menedžerje, menedžer } \\
\text { mentor skupini, } \\
\text { menedžer mentor } \\
\text { posamezniku }\end{array}$ & $\begin{array}{l}\text { - Učne metodologije, ki } \\
\text { omogočajo razvijanje } \\
\text { veščin vodenja za } \\
\text { svetovanje zaposlenim. } \\
\text { - Učne metode morajo } \\
\text { imeti končni cilj oz. } \\
\text { rezultat ustvarjanja } \\
\text { prihodkov organizacij. } \\
\text { - Da so menedžerji } \\
\text { podučeni, kako skrbeti } \\
\text { za zaposlene, jih znati } \\
\text { spodbujati, znati } \\
\text { vzpostavljati medsebojne } \\
\text { odnose in timsko delo. }\end{array}$ \\
\hline & & & & $\begin{array}{l}\text { - Glavni koncept učne } \\
\text { metodologije mora } \\
\text { sloneti na kulturi učenja, } \\
\text { katera doprinese, da } \\
\text { slušatelj želi uporabiti in } \\
\text { deliti svoje znanje. }\end{array}$ \\
\hline
\end{tabular}

\section{Razprava}

Na osnovi literature lahko sklepamo, da je andragoško/pedagoška podpora izobraževalnim programom za menedžerje dobrega počutja bistveno boljša v ZDA in EU kot v Sloveniji. Slovenija je na področju podpore izobraževalnih programov za menedžerje dobrega počutja še dokaj na začetku primerjalno z ostalimi regijami EU in ZDA. Izjeme so podjetja katera so v lasti svetovnih multinacionalk kjer se njihovi menedžerji poslužujejo izobraževanj dobrega počutja.

Podpora menedžerjem dobrega počutja v Sloveniji se vrši predvsem preko delavnic, seminarjev, medtem, ko imajo menedžerji v ZDA in EU bistveno več literature, internetnih 
izobraževanj in razvijajo aplikacije, ki omogočajo široko paleto rešitev za dobro počutje zaposlenih preko integriranih aplikacij.

Skozi raziskovanje smo ugotovili, da je izobraževanje menedžerjev dobrega počutja skozi kovčing v Sloveniji v porastu in se šele razvija. Takih izobraževanj se poslužujejo predvsem podjetja ki so povezana s tujino. Slovenija je zato na poti uporabe programov dobrega počutja in kovčinga pri izobraževanju menedžerjev še na začetku poti, medtem ko je kovčing v EU in ZDA že zelo razvit.

V zadnjih nekaj letih so $\mathrm{v}$ tujini začeli prepoznavati vrednost wellness programov, ki so namenjeni zaposlenim v delovnih organizacijah. Raziskave so pokazale, da so se v Združenih državah Amerike investicije v korporacijske wellness programe zvišale za kar 60 odstotkov. Pokazalo se je namreč, da takšni programi spodbujajo zaposlene, da prevzamejo bolj zdrav življenjski slog, s tem pa se v organizaciji znižajo stroški bolniških odsotnosti, ki so posledica zdravstvenih težav zaposlenih. Slednje so velikokrat posledica nezdravih življenjskih navad, kot so na primer kajenje, prekomerno uživanje alkohola, nezdravo prehranjevanje, nezadostna telesna dejavnost in podobno. (Skupina IRI, 2017, ods. 3)

Izobraževalni programi za menedžerje dobrega počutja so zelo pomembni, saj živimo v času hitrih sprememb kar ima za posledico stres. Stres je ključni dejavnik za izgorelost zaposlenih na delovnih mestih. Lastniki podjetij predvsem slovenskih se premalo zavedajo, da so taka izobraževanja za njihove zaposlene zelo pomembna. V kolikor bi se tega v večji meri zavedali bi se povpraševanje po takih izobraževanjih tudi bistveno povečalo. Dobili bi boljše programe za menedžerje dobrega počutja, s tem pa tudi kvalitetnejšo andragoško/pedagoško podporo.

\section{Zaključek}

Programi dobrega počutja izboljšajo vedenje zdravja zaposlenih, saj je bistvo izobraževalnih programov dobrega počutja sprememba vedenja. Program dobrega počutja zmanjšuje povečana zdravstvena tveganja in bistveno zmanjšuje stroške zdravstvene oskrbe, zmanjšajo absentizem, pomagajo izboljšati zaposlovanje in zadrževanje zaposlenih $\mathrm{v}$ delovnem razmerju in pomagajo vzdrževati visoko moralo zaposlenih. Vse to dosežemo z raznimi izobraževanji kot so kovčing, welness programi, metoda $360^{\circ}$, delavnice, ter razni spletni seminarji (webinarji) za menedžerje in ostala podpora izobraževalnim programom za menedžerje dobrega počutja.

Prispevek stroki oz. znanosti smo z raziskavo želeli dokazati, da je bistvenega pomena, vlaganje v izobraževanja menedžerjev dobrega počutja. Potrebno je razvijati izobraževalne programe v smeri zmanjševanja stresa za zaposlene na delovnih mestih. Menedžerje podučiti, da samo stres ne vpliva negativno na zaposlene temveč, da ima velik ekonomski vpliv zaradi odsotnosti zaposlenih zaradi bolniških odsotnosti. 
Z izobraževalnimi programi za menedžerje dobrega počutja lahko pozitivno vplivamo na zadovoljstvo in zdravje zaposlenih ter posledično na kakovostnejše življenje tako zaposlenih kot njihovih družinskih članov

Raziskava je bila omejena in narejena na podlagi teorije ter člankov in spletnih strani na podana raziskovalna vprašanja.

Iz članka je razvidno, da morajo biti menedžerji »dobrega počutja« dobro podkovani v znanju in poznavanju programa in vseh orodij oziroma prijemov, s katerimi bi lahko izobraževali in spodbujali zaposlene $\mathrm{k}$ dobremu počutju. Menedžer mora imeti sprotne informacije o izobraževalnih ponudbah, novostih in stalno slediti razvoju programov dobrega počutja.

V nadaljnjem raziskovanju bi se lahko preverilo, koliko organizacij ima vključene programe za »menedžerje dobrega počutja« v Sloveniji in na kakšne načine jih izvajajo (primeri dobrih praks). S tem bi ugotovili ali so cilji programa »menedžer dobrega počutja« doseženi, kar pomeni:

- Da imajo menedžerji, kateri so bili določeni za »menedžerja dobrega počutja« za zaposlene pridobljene ustrezne komunikacijske in vodstvene kompetence, katere pa se sprotno in najbolje izboljšajo z izobraževanji.

- Da imajo programi ali izobraževanja cilj, da usposobijo »menedžerja dobrega počutja« na katerikoli način (mišljen način učne vsebine), od seminarjev, delavnic do spletnih platform, da postane in vodi zaposlene z zgledom. Saj le s svojim obnašanjem lahko »menedžer dobrega počutja« svoje zaposlene vzgaja, motivira, obvladuje ter vzpostavlja neko ravnovesje med delom in osebnim življenjem zaposlenih.

- Da bi dober »menedžer dobrega počutja« poleg dobre komunikacije in odnosov med zaposlenimi imel tudi potrebna občasna neformalna in sprostitvena druženja med zaposlenimi - sodelavci ter nadrejenimi, tako imenovani »teambuildingi«.

- Da se razišče, kateri so tisti najbolj primerni vprašalniki za ocenjevanje oziroma samo ocenjevanje menedžerja dobrega počutja, da se lahko nato iz rezultatov najlažje razbere ali oceni ali so bili metode, pristopi usposabljanja »menedžerja dobrega počutja « pravilni in uspešni, ter da ima »menedžer dobrega počutja« pozitiven odnos do zaposlenih, je optimističen in ima močno samopodobo, vnaša upanje za uspešen razvoj, tako zaposlenih, kot same organizacije, gradi zaupanje med zaposlenimi, nudi psihološko podporo, ima visoko samospoštovanje ter, da je osredotočen na iskanje pozitivnih vrednost med zaposlenimi in ima 'enak pogled na svet' z zaposlenimi. 


\section{Reference}

1. 2Morrow Inc. (2017). Anytime, Anywhere Wellness Solutions for Employers \& Brokers. Pridobljeno na: https: //www.2morrowinc.com / broker sand employers ?be-119\&gclid=EAIaIQobChMI5azy7MeK5wIV2JrVCh0F9Aw0EAAYASAAEgL8vvD_BwE.

2. Aldana, S. (2020, 2. januar). 7 most important reasons to offer employee well-being at work. Pridobljeno na: https://www.wellsteps.com/blog/2020/01/02/employee-well-being.

3. Berlogar, J. (1997). Kritična interpretacija kakovosti v izobraževanju odraslih. AS. Andragoška spoznanja, letnik 3, številka 3/4. Str. 34-41. URN:NBN:SI:doc-oW1GKFOL Pridobljeno na: http://www.dlib.si.

4. Bersin. J. (2017). HR technology disruptions for 2018: Productivity, design and intelligence regin. Bersin, Deloitte Consulting LPP. Pridobljeno na: https://www2.deloitte.com/us/en/insights/focus/human-capital-trends/2018/employee-well-beingprograms.html.

5. Brečko, D. (1996). Marketinški pristop v izobraževanju odraslih. Andragoška spoznanja, Letnik 2, leto 1996, št. 4.

6. Čeč, F. (2006). S coachingom do večjih poslovnih in osebnih dosežkov. Zagorje ob Savi: Regionalni center za razvoj.

7. Čelebič, T. (2018). Znanje in spretnost prebivalcev v Sloveniji. Ljubljana: Urad RS za makroekonomske analize in razvoj.

8. Deci, E. L., and Ryan, R. M. (2008). Hedonia, eudaimonia, and well-being: An introduction. Journal of happiness studies, 9(1), 1-11.

9. Deloitte Insights. (2018, 28. marec). Well-being: A strategy and responsibility. Pridobljeno na: https://www2.deloitte.com/us/en/insights/focus/human-capital-trends/2018/employee-well-beingprograms.html.

10. Diener, E., Wirtz, D., Tov, W., Kim-Prieto, C., Choi, D. W., Oishi, S., Biswas-Diener, R. (2010). New well-being measures: Short scales to assess flourishing and positive and negative feelings. Social Indicators Research, 97(2), 143-156. Pridobljeno na: http://www.mysmu.edu/faculty/williamtov/pubs/2009_DienerEtAl.pdf

11. Eurofond. (2020, 16. januar). Healt and well-being at work. Pridobljeno na: https://www.eurofound.europa.eu/topic/health-and-well-being-at-work.

12. EU-Startups. (2019 26. julij). 10 European startups improving employee well-being. Pridobljeno na: https://www.eu-startups.com/2019/07/10-european-startups-improving-employee-well-being.

13. Ferjan, M. (1996). Skrivnosti vodenja šole k znanju, uspehu in ugledu. Radovljica: Didakta.

14. Global Wellness Institute. (2016, 17. februar). Global Wellness Institute releases report and survey on the future of wellness at work. Press release, February 17, 2016. Pridobljeno na: https://www2.deloitte.com/us/en/insights/focus/human-capital-trends/2018/employee-well-beingprograms.html.

15. HR\&M. ( 2020, 25. januar). Strokovna revija za področja razvoja organizacij in razvoja ljudi pri delu. Pridobljeno na: https://spletna.hrm-revija.si

16. IBISWorld. (2016). Corporate Wellness Services in the US. February 2016, p.5. Pridobljeno na: https://www2.deloitte.com/us/en/insights/focus/human-capital-trends/2018/employee-well-beingprograms.html.

17. Kaplan, R. M., Sieber, W. J., Ganiats, T. G. (1997). The quality of well-being scale: comparison of the interviewer-administered version with a self-administered questionnaire. Psychology and Health, 12(6), 783-791. 
18. Klemenčič, S., Možina, T., Žalec, N. (2009). Kompetenčni pristop k spopolnjevanju andragoških delavcev. Ljubljana: Andragoški center Slovenije.

19. Kohont, A. (2019). Menedžment človeških virov: stično področje za svetovanje v izobraževanju zaposlenih. Ljubljana: Andragoški center Slovenije.

20. Koren Sports Group. (2010). Korporacijski wellness program. Pridobljeno na: https://www.korensports.si/KOREN_SI,programi,programi_za_podjetja,korporacijski_wellness_program.htm.

21. Kotler, P., Fox, F.A. (1995). Strategic Marketing for Educational Institutions. Preutic-Hall, Inc., Englewood Cliffs, New Jersey.

22. Krek, J. (1997). Bela knjiga o vzgoji in izobraževanju v Republiki Sloveniji. Ljubljana: Ministrstvo za šolstvo in šport

23. Lešnik, V. (2008). Razvijajte svoje zaposlene. Podjetnik. XVII, št. 11/2008.

24. Matke, S., Liu, H., Caloyeras, J., Huang, C. Y., Van Busum, K. R., Hhodyakov, D., Shier, V. (2013, 1. junij). Workplace Wellness Programs Study. Pridobljeno na: https://www.ncbi.nlm.nih.gov/pmc/articles/PMC4945172/.

25. Mednarodna organizacija dela, (1996-2020). Dobro počutje na delovnem mestu. Pridobljeno na: https://www.ilo.org/safework/areasofwork/workplace-health-promotion-and-wellbeing/WCMS_118396/lang--en/index.htm.

26. Mlinar, V. (2019). Ocenjevanje kompetenc zaposlenih. Ljubljana: Andragoški center Slovenije.

27. Nef. (2019). Five ways to wellbeing. Pridobljeno na: https://www.businessballs.com/freespecialresources/Five_Ways_to_Well-being-NEF.pdf.

28. Nieboer, A., Lindenberg, S., Boomsma, A., Bruggen, A. C. V. (2005). Dimensions of well-being and their measurement: the SPF-IL scale. Social Indicators Research, 73(3), 313-353. Pridobljeno na: http://lindenberg.academiaworks.com/articles/2005_Nieboer_etal-Dimensin_of_well-being.pdf

29. OPG. (2017). Who We Are. Pridobljeno na: https://organizationalperformancegroup.com/who-weare.

30. Praštalo, R. (2010). Timski coaching i razvoj karijere pojedinca v timu. Ljubljana: Glotta Nova d.o.o.

31. Schwartz, J., Agarwal, D., Bersin, J., Lahiri, G., Volini, E. (2014). The overwhelmed employee: Simplify the work environment. Deloitte University Press, March 7, 2014. Pridobljeno na: https://www2.deloitte.com/us/en/insights/focus/human-capital-trends/2018/employee-well-beingprograms.html.

32. Skupina IRI. (2017). Wellness program v našem podjetju? Pa poskusimo! Pridobljeno na: http://www.iri-lj.si/gradivo/clanki/72-wellness-program-v-nasem-podjetju.

33. The Resilience Institute. (2020). Online, face-to-face and blended. Pridobljeno na: https://resiliencei.com/training.

34. Traven, S. $\left(2005^{\mathrm{a}}\right)$. Premagovanje stresa. Ljubljana: GV založba.

35. Velikonja, M. (2012). Andragoško vodenje učno gradivo za vodje izobraževanj odraslih in učiteljev. Ljubljana: Ministrstvo RS za izobraževanje, znanost, kulturo in šport.

36. Velnes.si. (2020). Kdo je lahko coach v podjetju? Pridobljeno na: http://www.velnes.si/kdo-jelahko-coach-v-podjetju.

37. Vilič Klenovšek, T. (2019). S svetovanjem za zaposlene do večje vključenosti v izobraževanje in usposabljanje. Ljubljana: Andragoški center Slovenije.

38. Žižek, Š. S., Bregenzer, A., Eibel, K., Hofer, C., Ivanovič, B., Jimenez, P., ... Treven, U. (2013). Premagovanje stresa kot sredstvo za zagotavljanje dobrega počutja. Maribor: Ekonomskoposlovna fakulteta. Pridobljeno na: 


\begin{abstract}
$* * *$
Andrej Mohar inženir strojništva in diplomirani organizator, zaposlen v podjetju, katero ima močan lastni razvoj in širok portfelj lastnih proizvodov, ki so pretežno namenjeni obrambnim silam in policijskim enotam, pa tudi podjetjem, ki se ukvarjajo s proizvodnjo vojaškega orožja in opreme; oddelek kakovosti.
\end{abstract}

$* * *$

Boštjan Zagorc diplomiral na fakulteti za organizacijske študije v Novo mesto smer menedžment kakovosti in si pridobil naziv diplomirani organizator. Zaposlen v tovarni pohištva kot vodja proizvodnje.

\title{
Abstract: Andragogical/Pedagogical Support for Well-Being Education Programs
}

Research Question (RQ): What are the most appropriate formats for learning content for target groups? What type of assessment framework would be most appropriate to facilitate the measurement of attainment? What types of pedagogic supports are needed to facilitate the involvement of participants (work well-being managers) into the program framework? What are the most appropriate teaching and learning methodologies for work well-being managers?

Purpose: The purpose and aim of the research is to compare andragogical / pedagogical support for wellness managers' educational programs between Slovenia and the EU and the USA.

Method: With the qualitative research method, we examined the theoretical starting points of our research. We obtained information from various articles and magazines on the topic of well-being educational programs.

Results: Andragogical / pedagogical support of well-being educational programs is significantly better in the US and EU than in Slovenia. In the area of support for well-being managers educational programs, Slovenia is relatively early on compared to other countries such as the EU and USA.

Organization: The survey can have a positive impact on managers and society, as it has shown that educational programs for well-being managers can have a positive impact on employee satisfaction and health and, consequently, on the quality of life of both employees and their superiors.

Society: The research can have a positive impact on managers and society, as it has shown that educational programs for well-being managers can have a positive impact on employee satisfaction and health and, consequently, on the quality of life of both employees and their family members.

Originality: The research provides a comprehensive overview of the sample survey of all content found on the topic of andragogical / pedagogical support for well-being managers.

Limitations/Future Research: The research was limited more to education and training programs, as there are not many articles on the topic of andragogical / pedagogical support for well-being managers.

Keywords: manager, education, well-being, stress, media formats, andragogical coaching. 